\title{
ELIZABETH CRUICKSHANK RECEIVES HONORARY DEGREE
}

\begin{abstract}
MARGARET BELCHER, 2601 Winnipeg Street, Regina, Saskatchewan, S4P $1 \mathrm{H} 8$.
\end{abstract}

EDITOR'S NOTE: On 23 May 1980 , Elizabeth Cruickshank, Honorary President of the Saskatchewan Natural History Society was presented the degree of Doctor of Laws honoris causa at the Spring Convocation of the University of Regina. Most readers of the Blue Jay will know Mrs. Cruickshank only as a naturalist, and because Margaret Belcher's citation outlines other areas of her busy life, we are pleased to reprint the citation in it's entirety.

Eminent Chancellor; it is my privilege, on behalf of the University Council and Senate, to present to you ELIZABETH ROLEY CRUICKSHANK, MBE.

In January 1916, a vibrant young teacher from New Brunswick arrived in Regina. Facing our proverbial 50below-zero weather in a suit and button boots, Elizabeth Keirstead did not think she would like Saskatchewan. Yet she stayed to teach in the city, married W. K. Cruickshank of Andrews and Cruickshank, analytical chemists, and in 1980 (64 years later) celebrates Saskatchewan with us at this Convocation.

Very many of you in this audience know Elizabeth Cruickshank as "Liz Roley" of the Regina Leader Post. Her "Nature Notes" have appeared weekly for 25 years, and a selection of them was published in book form (in 1976) under the title $A$ Second Look. For a number of years Mrs. Cruickshank also wrote nature scripts for the CBC's school broadcasts and spoke to hundreds of visitors to the
Saskatchewan Museum of Natural History, where she manned the information desk and the Blue Jay Bookshop. Always, young people have sought her out and have been stimulated by her enthusiasm. She has been an active member and executive officer of both the Regina and Saskatchewan Natural History Societies, and is now Honorary President of the latter. In 1968, she received the provincial society's Conservation Award.

In all her activities as a naturalist, Elizabeth Cruickshank's mission has been to inculcate the habit of "a second look", to teach us

To see a world in a grain of sand, And a heaven in a wild flower.

Many and impressive are the contributions that Elizabeth Cruickshank has made to the "quality of life" in this city and province. Particularly in the depressed years of the 1930's and during the Second World War, her warm and courageous acts of service rallied the spirits of a beleaguered society. She was a member of the Regina Welfare Bureau and the Regina Relief Board, and used her free time to run a sewing room where women made quilts and clothes for people on relief. She was President of the Regina Council of Women (which in 1975 made her a life member), and Vice-President of the Community Chest. She served on the executive of the Children's Aid Society and worked with cases before the juvenile courts. She organized the Grace Haven Auxiliary to the Salvation Army, and later 


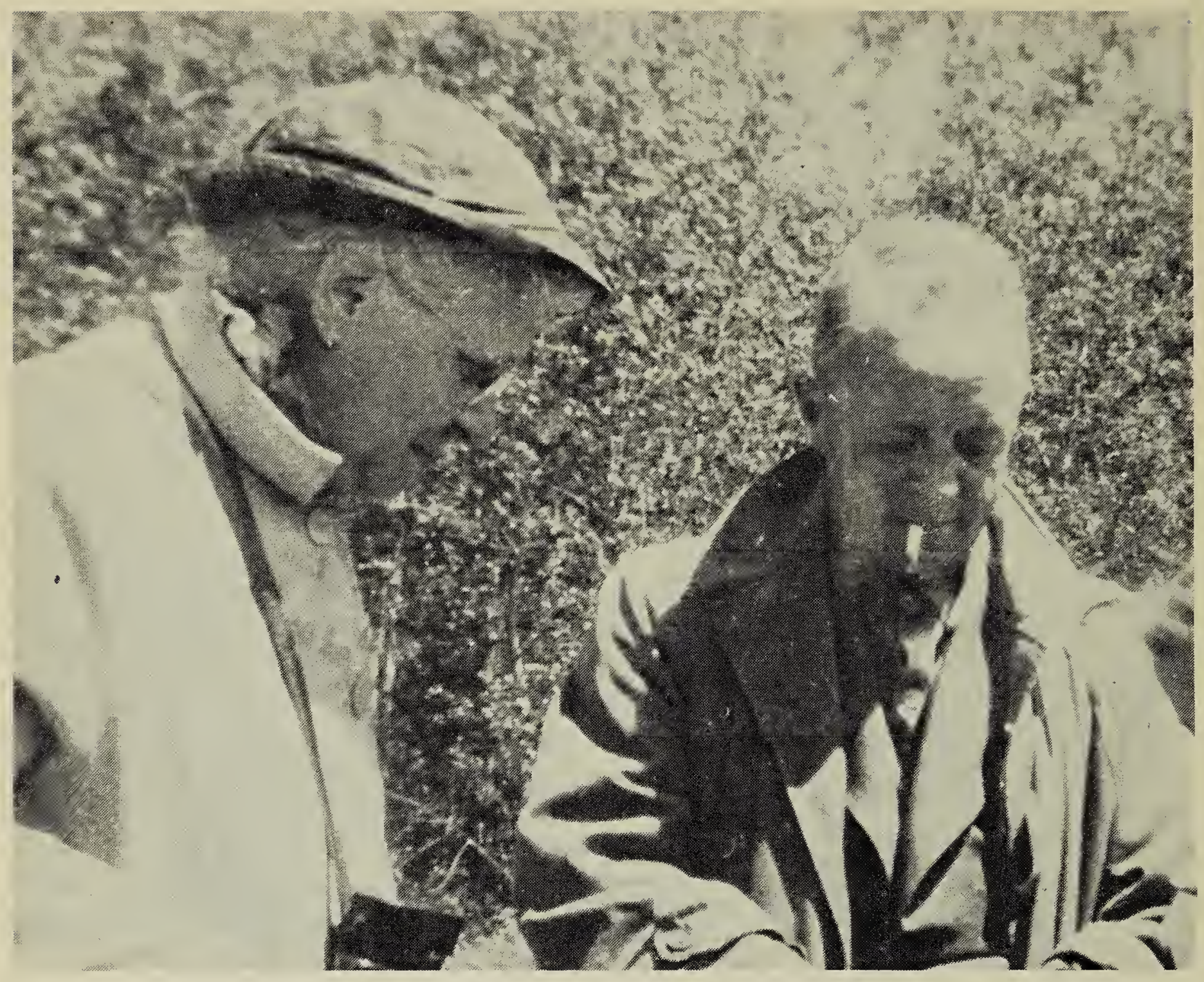

Elizabeth Cruickshank with Cliff Shaw.

served on a C.N.I.B. committee and on the Saskatchewan Social Services Council.

During the war years, Elizabeth Cruickshank was chairman of women's activities for the Saskatchewan section of the National War Finance Committee. She organized more than 400 women's committees, travelling throughout Saskatchewan. On the Dependents' Board of Trustees, she dealt with problems faced by wives of service men overseas. As President of the Provincial Council of Women, she was the one woman member of the Reconstruction Council chaired by Dean Cronkite advising the government on the rehabilitation of returned men. For this extensive volunteer war work, she was awarded the Order of the British Empire.

Elizabeth Cruickshank is still today a leader in her church, and a popular guest speaker. She is a charter member of the Regina branch of the Canadian Women's Press Club (now the Media Club), and was one of 12 journalists selected to receive the 1967 Centennial Medal.

The granting of an honorary degree is a traditional University ceremony honouring distinguished citizenship. Therefore, Eminent Chancellor, on behalf of the Council and Senate of the University of Regina, I present to you ELIZABETH ROLEY CRUICKSHANK, and ask that you confer on her the degree of Doctor of Laws honoris causa. 